\title{
Esophageal Actinomycosis in an acute myeloid leukemia patient
}

\section{Akut myeloid lösemili bir hastada gelişen özefagial Aktinomikoz}

\author{
Soner Solmaz ${ }^{1}$, Aslı Korur ${ }^{2}$, Çiğdem Gereklioğlu² ${ }^{2}$ Barış Soydaş ${ }^{3}$, Özlem Doğan ${ }^{3}$, \\ Bermal Hasbay ${ }^{4}$, Yusuf Ziya Demiroğlü ${ }^{5}$, Can Boğa ${ }^{1}$ \\ 1Department of Hematology, Adana Hospital of Başkent University, Adana, Turkey \\ 2Department of Family Medicine, Adana Hospital of Başkent University, Adana, Turkey \\ 3Department of Gastroenterology, Adana Hospital of Başkent University, Adana, Turkey \\ 4Department of Pathology, Adana Hospital of Başkent University, Adana, Turkey \\ 5Department of Infectious Diseases, Adana Hospital of Bașkent University, Adana, Turkey \\ Corresponding author: Soner Solmaz, Department of Hematology, Adana Hospital of Başkent University, Adana, Turkey \\ E-mail: drssolmaz@gmail.com \\ Received/Accepted: October 06, 2015 / April 01, 2016 \\ Conflict of interest: There is not a conflict of interest.
}

\section{SUMMARY}

Actinomycosis is a chronic disease characterized by abscess formation, tissue fibrosis, and draining sinuses. While cervical and thoracic localizations are most frequent, digestive actinomycosis is rare. To the best of our knowledge, actinomycosis-related esophageal involvement has not been reported previously in a patient with acute myeloid leukemia. Therefore, we wanted to report this esophageal actinomycosis case presenting with odinophagia and dysphasia.

Keywords: Actinomycosis, acute myeloid leukemia, esophagus.

\section{ÖZET}

Aktinomikoz, abse oluşumu, doku fibrozisi ve drene olan sinüslerle karakterize kronik bir hastalıktır. Servikal ve torasik yerleşim en sık görülen formlar iken sindirim sistemi tutulumu nadirdir. Bilgilerimize göre, akut myeloid lösemili bir hastada gelişen aktinimikoz ilişkili özefagial tutulum daha önce rapor edilmemiştir. Bundan dolayı, odinofaji ve disfaji ile başvuran özefagial aktinomikoz vakası sunulmuştur.

Anahtar sözcükler: Aktinomikoz, akut myeloid lösemi, özefagus.

\section{INTRODUCTION}

Actinomycosis is an infrequent invasive bacterial disease that has been recognized for over a century [1]. Actinomycosis is a chronic disease characterized by abscess formation, tissue fibrosis, and draining sinuses [2]. To date, multiple different clinical features of actinomycosis have been described, as various anatomical sites (such as face, bone and joint, respiratory tract, genitourinary tract, digestive tract, central nervous system, skin, and soft tissue structures) can be affected [1]. While cervical and thoracic localizations are most frequent, digestive actinomycosis is rare [3] To the best of our knowledge, actinomycosisrelated esophagitis or esophageal ulcer has not been reported previously in a patient with acute myeloid leukemia (AML).

\section{CASE REPORT}

A 68-year-old male patient diagnosed with AML-M1 and received 5-azacytidine was admitted to our clinic with complaints of retrosternal pain, odinophagia and dysphagia gradually increasing since 2 weeks. He was learned to have experienced problems with his dental prothesis and underwent a dental intervention. His physical examination findings 
were normal except a couple of dental caries and pallor. Laboratory examinations were as follows: Hemoglobin10.5 gr/dL, hematocrit $31.8 \%$, white blood cell count $0.7 \times 103 / \mathrm{mcL}$, platelet count $221 \times 103 / \mathrm{mcL}, \mathrm{CRP} 22.5 \mathrm{mg} / \mathrm{dL}$ (0-6.0 $\mathrm{mg} / \mathrm{dL}), \quad$ ESR $114 \mathrm{~mm} / \mathrm{hr}$. Esophagogastrodeudenoscopy revealed a couple of esophageal ulcers measuring approximately 3-4 $\mathrm{mm}$ in distal esophagus. Microscopic examination of the specimens obtained from esophagus revealed mixed type inflammatory cell infiltration rich from eosinophils on mucosa lined with stratified epithelium, sulfur granules and spherical structures consistent with actinomycosis neighboring to epithelium (Figure 1). No esophageal pathologies were detected on computed tomography of thorax and abdomen. The patient was evaluated by infectious diseases specialist and treatment was started with ampicillin/sulbactam 1.5 gr quid via intravenous route. The symptoms of the patient disappeared within a couple of days and completely resolved after 6 weeks of antibiotic treatment and lesions were detected to recover on control endoscopy examination.

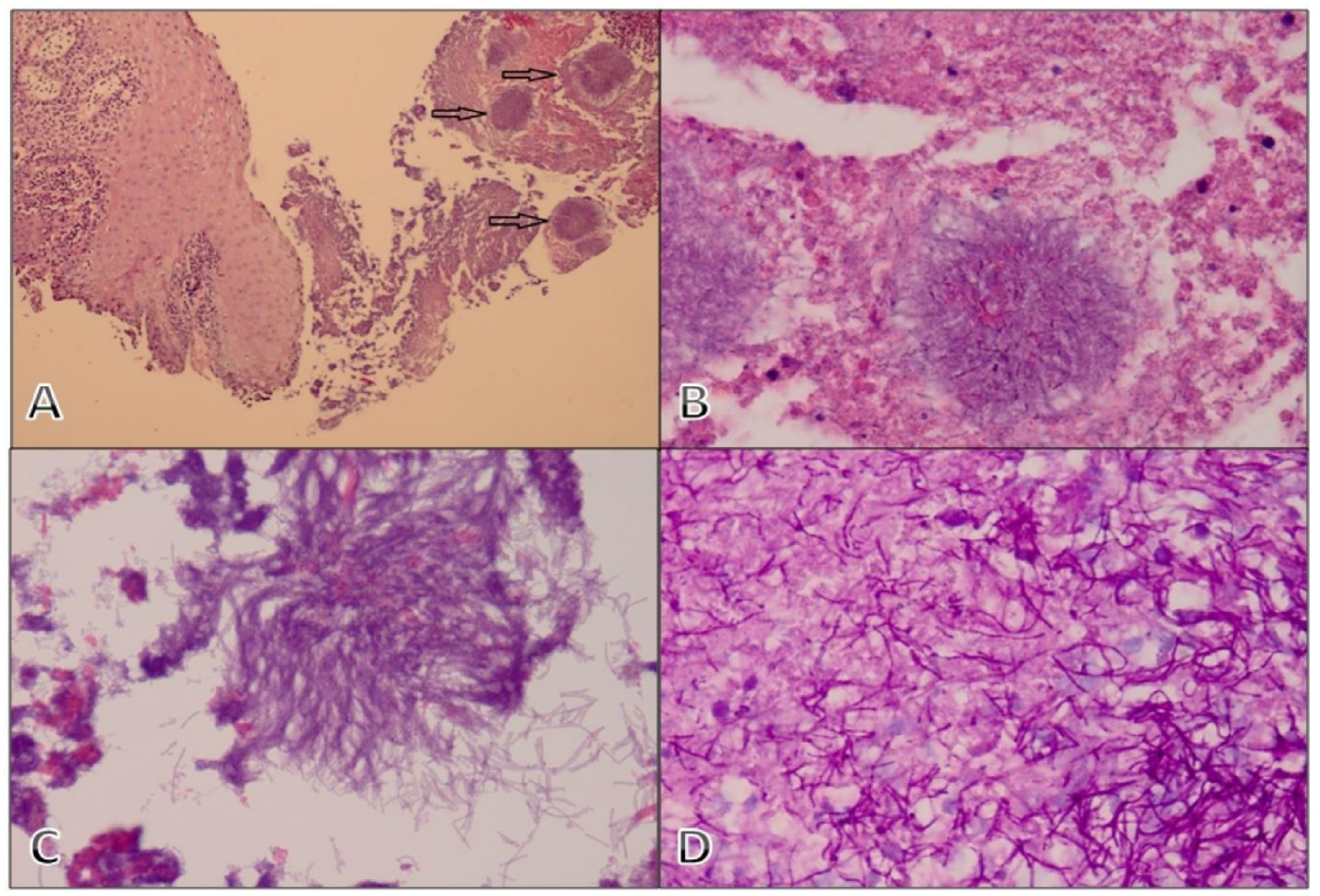

Figure 1. Spherical structures and sulfur granules within the necrotic fibrinoid material near esophagus mucosa, consistent with Actinomyces (Hematoxylin and Eosin (HE), x100) [A], high magnification of Actinomyces colonies (HE, x400; HE, x600) [B,C], PAS positive stained colonies and surrounding fine, branched bacilli (PAS stain, x1000) [D].

\section{DISCUSSION}

Actinomycosis is a gram-positive anaerobic bacterium that normally colonize the mouth, colon, and urogenital tract $[4,5]$. Actinomyces species and the closely related Nocardia species, which were once believed to be fungi because of their branching filaments, are now classifies as higher prokaryotic bacteria [2]. Of the 14 Actinomyces species, six may cause disease in humans, including the faculatively $A$. 
israelii, A.naeslundii, A. odontolitycus, A. viscosus, A. meyeri, and A. gerencseriae [2]. They are considered as an oppurtunistic infection in immunocompromised patients such as malignancy, human immunodeficiency virus infection, diabetes mellitus, steroid usage or alcoholism [6]. Four clinical forms of actinomycosis, i.e., cervicofacial, thoracic, abdominapelvic, and cerebral, account for the majority of infections in humans [2].

The face and neck are the most common sites of actinomycosis [2]. Actinomyces species are normally present in high concentrations in tonsillar cyripts and gingivodental crevices, and many infections are odontogenic in origin [2]. Cervicofascial actinomycosis may take the form acute, painful pyogenic abscesses or indolent disease [2]. The latter process may evolve into a painless indurate mass in the face or neck, often accompanied by one or more draining sinus tracts that discharge sulfur granules [2]. Thoracic actinomycosis may involve the lungs, pleura, mediastinum, or chest wall [2]. Abdominal actinomycosis usually occurs following penetrating trauma, perforation of the gut, or surgical manipulation of the gastrointestinal tract [2]. Actinomycosis of the CNS may present as brain abscess, meningitis or meningoencephalitis, subdural empyema, actinomycoma, and spinal and cranial epidural abscess [2].

Esophageal involvement has seldomly been reported both in immunocompromised and immunocompetent patients compared to its common clinical forms $[6,7,8,9]$. Esophageal involvement of actinomycosis was usually reported as esophagitis or esophageal ulcer which lead to odinophagia and dysphagia $[7,9]$. Abdalla et al. reported an actinomycosis esophagitis which developed in a patient who was receiving chemotherapy and radiotherapy due to lung cancer [7]. Afolabi and Shashidhar have reported a patient who was admitted with dysphagia and mimicking esophageal cancer [8]. Lee et al. reported an esophageal actinomycosis developing in a patient with AIDS [9]. Kim et al. reported an esophageal actinomycosis which developed in an immunocompetent patient [6].

Bacterial cultures and pathology are the cornerstone of diagnosis [1]. Bacteriological identification of Actinomyces from a sterile site confirms the diagnosis of actinomycosis [1]. However, isolation and identification of these causative bacteria occur in only a minority of cases; the failure rate of culture is high because of previous antibiotic therapy, inhibition of Actinomyces growth by contaminant and/or microorganisms, inadequate culture conditions, or inadequate short-term incubation [1]. Gram staining of pus and pathology of infected tissue is of great interest for the diagnosis of actinomycosis, as it is usually more sensitive than culture, which remains sterile in more than $50 \%$ of cases [1]. Typical microscopic findings include necrosis with yellow fish sulfur granules and filamentous Gram-positive fungal like pathogens [1]. Yellowish sulfur granules are constituted by conglomeration of bacteria trapped in biofilm [1]. We did not obtain microbiological specimens as the lesions were as ulcers but not in abscess formation, therefore the diagnosis of esophageal actinomycosis was not considered. The diagnosis was made based on histopathological examination in our case. Differently from the other clinical forms of actinomycosis, making a histopathologic diagnosis seems to come in the foreground in esophageal involvement.

In conclusion, an ample amount of medications, infectious agents (herpes virus, candida, cytomegalovirus, human immune deficiency virus, human papilloma virus) and chemical factors (e.g., gastric ascites) are known to cause esophagitis and esophageal ulcer. However actinomyces-related esophagitis or esophageal ulcer has not been reported previously. Therefore it is difficult to consider actinomycesrelated esophagitis and esophageal ulcer in differential diagnosis in a patient with acute leukemia. It should be kept in mind that actinomyces may be a causative agent for esophagitis or esophageal ulcer in a leukemia patient, especially dental procedures performed. 


\section{REFERENCES}

1. Valour F, Sénéchal A, Dupieux C, Karsenty J, Lustig S, Breton P, Gleizal A, Boussel L, Laurent F, Braun E, Chidiac C, Ader F, Ferry T. Actinomycosis: etiology, clinical features, diagnosis, treatment, and management. Infect Drug Resist 2014; 7:183-97.

2. Smego RA Jr, Foglia G. Actinomycosis. Clin Infect Dis 1998; 26:1255-61.

3. Benkhraba K, Benkabbou A, El Malki HO, Amahzoune M, Mohsine R, Ifrine L, Belkouchi A, Balafrej S. Digestive actinomycosis: three cases and review. Gastroenterol Clin Biol 2006;30:775-8.

4. Chen CY, Chen YC, Tang JL, Lin $\mathrm{WC}, \mathrm{Su}$ IJ, Tien HF. Splenic actinomycotic abscess in a patient with acute myeloid leukemia. Ann Hematol 2002; 81:532-4.

5. Acevedo F, Baudrand R, Letelier LM, Gaete P. Actinomycosis: a great pretender. Case reports of unusual presentations and a review of the literature. Int J Infect Dis 2008; 12:35862.

6. Kim HS, Cheon JW, Kim MS, Jung CK, Kim KR, Choi JW, Kang DW, Kim SY.A case of esophageal actinomycosis in a patient with normal immunity. Korean J Gastroenterol 2013; 61:93-6.

7. Abdalla J, Myers J, Moorman J. Actinomycotic infection of the oesophagus. J Infect 2005; 51:E39-43.

8. Afolabi IR, Shashidhar VM. Carcinoma of the oesophagus masquerading as actinomycosis: a case report and a review of literature. Pac Health Dialog 2004; 11:94-5.

9. Lee SA, Palmer GW, Cooney EL. Esophageal actinomycosis in a patient with AIDS. Yale J Biol Med 2001; 74:383-9. 